
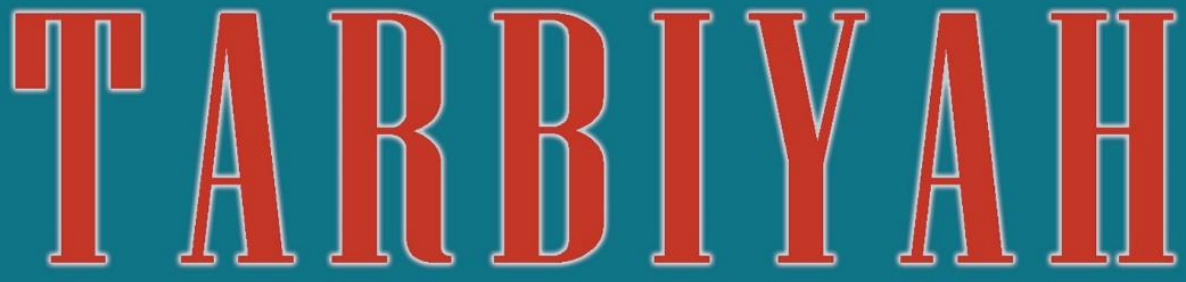

INTEGRATION OF ISLAMIC VALUES IN ENGLISH LEARNING AT MADRASAH IBTIDAIYAH TEACHER TRAINING PROGRAM (PGMI) UIN NORTH SUMATERA

THE IMPORTANCE OF THE EFFECTIVENESS LEADERSHIP CONCEPT IN BUILDING ISLAMIC EDUCATION

LEADERSHIP POLICY IN DEVELOPING OF ISLAMIC SCHOOL EDUCATION CURRICULUM AT DARUL ARAFAH BOARDING SCHOOL IN DELI SERDANG REGENCY

CONTRIBUTION OF MAHMUD YUNUS ISLAMIC EDUCATION LEARNING METHOD IN AL-TARBIYAH WA-ALTA'LIM BOOK

ISLAMIC EDUCATION PERSPECTIVE IMAM AL-GHAZALI AND IT'S RELEVANCE WITH EDUCATION IN INDONESIA

THE EFFECT OF WORK MOTIVATION AND WORK STRESS ON TEACHER PERFORMANCE

HUMANISTIC CHARACTER EDUCATION CURRICULUM MODEL IN SDIT NURUL FIKRI ACEH BESAR

STUDY OF EXPOSITION PARAGRAPH DEVELOPMENT INTARBIYAH AND TEACHER TRAINING FACULTY STUDENTS

MULTICULTURAL EDUCATION IN MADRASAH DINIYAH AS PREVENTION OF RELIGIOUS CONSERVATISM

THE IMPROVEMENT OF STUDENT'S MATHEMATICAL COMMUNICATION ABILITY BY USING COOPERATIVE LEARNING: COURSE REVIEW HORAY 


\section{JURNAL TARBIYAH}

Published biannually, January-June and July-December editions, containing scientific articles of tarbiyah, Islamic education, conceptual, research results, study of books and biographies of figures

\section{Chancellor}

Dean Fakultas Ilmu Tarbiyah dan Keguruan UIN Sumatera Utara Medan

\section{Editor in Chief}

Mesiono

\section{Editors}

Junaidi Arsyad

Sakholid Nasution

Eka Susanti

Sholihatul Hamidah Daulay

Maryati Salmiah

\section{Reviewers}

Ayang Utriza Yakin, Universitas Islam Negeri Syarif Hidayatullah Jakarta, Indonesia Rahmah Fithriani, Universitas Islam Negeri Sumatera Utara Medan, Indonesia Irwan Padli Nasution, Universitas Islam Negeri Sumatera Utara Medan, Indonesia Firman, Universitas Negeri Padang, Indonesia

Nafan Tarihoran, IAIN Sultan Maulana Hasanuddin Banten, Indonesia Jamal, Universitas Negeri Bengkulu, Indonesia

Khairil Ansyari, Universitas Negeri Medan, Indonesia

Ibnu Hajar, Universitas Negeri Medan, Indonesia

Saiful Anwar, Institut Agama Islam Negeri Raden Intan Lampung, Indonesia

\section{Graphic Design}

Suendri

\section{Secretariat}

Reflina

Nurlaili

Sahlan 


\title{
LEADERSHIP POLICY IN DEVELOPING OFISLAMIC SCHOOL EDUCATION CURRICULUM AT DARULARAFAH BOARDING SCHOOL IN DELI SERDANG REGENCY
}

\author{
Mhd. Hamzah', Syafaruddin², Syaiful Akhyar3 \\ ${ }^{1}$ Kementerian Agama Kabupaten Aceh Tengah, Aceh, Indonesia \\ 2,3 Universitas Islam Negeri Sumatera Utara, Medan, Indonesia \\ Email: mhd.hamzah@gmail.com
}

DOI : 10.30829/tar.v26i1.422

Date submitted : 22 May 2019

Published : 3o June 2019

\begin{abstract}
Abstrak: Penelitian ini bertujuan untuk mengetahuiproses perumusan, pelaksanaan kebijakan, kinerja, dan dukungan stakeholders, kebijakan pimpinan pesantren dalam pengembangan kurikulum pendidikan madrasah di pesantren Darularafah Lau Bakeri Kabupaten Deli Serdang. Data diperoleh melalui wawancara, observasi, dan dokumentasi. Analisis data dilakukan melalui reduksi data, penyajian data, dan verifikasi data. Hasil penelitian ini yaitu 1) Perumusan kebijakan pimpinan pesantren dilakukan melalui rapat tahunan dan musyawarah yang dihadiri oleh para pimpinan, ketua bidang, para kepala sekolah/madrasah, guru-guru serta masyarakat merumuskan lima program kerja dalam kaitannya dengan sistem gerakan, organisasi dan kepemimpinan, jaringan, sumber daya dan aksi pelayanan, 2) Pelaksanaan rumusan program pengembangan kurikulum yang diterapkan di pesantren Darularafah dilakukan setiap akhir tahun, selanjutnya disosialisasikan kepada dan melalui Bidang-bidang yang telah disusun, 3) Kinerja pelaksanaan kebijakan pimpinan pesantren disesuaikan dengan perkembangannya serta sesuai dengan kebutuhan pesantren, 4)Dukungan stakeholders dalam pelaksanaan kebijakan pimpinan pesantren bahwa sangat mendukung di lingkungan internal, begitu pula dari eksternal/masyarakat.
\end{abstract}

Kata Kunci: Kebijakan, Pimpinan Pesantren, Pengembangan Kurikulum.

Abstract: This study aimed to determine the process of formulating policies, implementing policies, performance, stakeholders support, and the policies of the boarding chairman in developing the Islamic school curriculum at the Darularafah Boarding School boarding school in Deli Serdang Regency. The data were obtained through interviews, observation, and documentation. The data analysis was done through data reduction, data presentation, and data verification. The results of this study were 1) The formulation of boarding school leaders' policies was carried out through annual meetings and deliberations attended by chairman, chiefs of fields, principals, teachers and communities to formulate five work programs related to the system of movement, organization and leadership, network, resources, and actions of service, 2) Implementation of formulation of the curriculumdevelopment program implemented at the Darularafah boarding school was carried out at the end of each year, then socialized to and through the prepared fields. 3) the performance of the implementation of the boarding schoolleadershippolicy was suited to its development as well as the boarding school's needs, 4) Stakeholder supported in implementing the policies of the boarding 
school leadership that was very supportive in the internal environment, as well as from the external / community.

Keywords: Policy, leadership of Islamic Boarding School, Curriculum Development.

مستخلص : يستهدف البحث لمعرفة عملية التخطيط وتنفيذ القرار والأداء ودعم مستخدمي الخريج وقرار رؤسـاء بمعهد دار العرفة منطقة ديلي سيردانج. كسبت البيانات من خلال المقابلة والملاحظة والوثائق. حللت البيانات بتخفيضها وعرضها وتحقيقها. نتائح البحث هي: 1). عقد تخطيط القرار بمعهد دار العرفة من خلال المقابلة السنويـة التى يجخضرها الرؤساء ورئيس القسم ورؤسـاء الملدرسة والمدرسون والمجتمع الذين ينظمون البرامج العملي وعلاقتها بنظام الحركي والجمعيـة والرئاسـة والشبكة والموارد والخدمة. 2). تنفيذ تخطيط البرنامج لتطوير المنهج المنفذ بمعهد دار العرفة عقد كل أواخر السنة ثم ترويـجها لدى المجالات المرتبـة. 3). أداء تنفيذ قرار رؤسـاء المعهد يناسب مع تطورها واحتياج المعهد. 4). دعم مستخخدمي الخربج في تنفيذ قرار رؤسـاء المعهد كبير جدا داخليا كان أم خارجيا. الكلمات المفتاحية: القرار، رؤساء المعهد وتطورير المنهج.

\section{Introduction}

The creation of a modern organizational culture in education is very important. Modern organizational culture will shape people in high discipline, form a character and attitude that is responsible for their work and has a soul in service to the public interest. If this is applied in the world of education, good quality will soon be apparent. Effective organizational culture for educational institutions requires collaboration and cooperation among the communities, both internal and external. Collaboration and intensive cooperation can only be achieved when growing from management styles and effective leadership patterns.

Islamic boarding schools are referred to as organization, because Islamic boarding schools are educational institutions which are developed with unique management, namely the application of religious values that are the basis of organizational development in every changing era. The role of leaders in improving the quality of education in Islamic boarding schools is always inviting to explore and a comprehensive 
study is needed on the intricacies of the struggle of Islamic boarding schools in responding to the challenges of the times and the surrounding reality. Islamic boarding schools have had a very big role in developing human resources. Islamic boarding schools have become a center of excellence for the development of human resources who have a base of morality in social life. Countless number of boarding school alumni have become scholars, clerics and religious leaders at both local and national levels.

Darularafah Boarding School is one of the boarding schools in Deli Serdang Regency. In the learning process the boarding school still uses the EducationalUnit Level Curriculum (KTSP) in which this curriculum is prepared on the basis of the components required by each teacher. Then the goals, educational programs, delivery systems, evaluations, and so on should be planned in such a way that is relevant to the demands of teacher competence in general. So far the lesson plan has been patterned and developed from the start made by the teachers of each field of study, with reference to the StandardCompetencies (SK), Basic Competencies (KD) which can be developed as a reference for carrying out classroom learning activities.

The use of curriculum KTSP in the learning process that is currently taking place is caused by several considerations from the leadership, one of which is because there are several considerations that can be used as the basis and reasons why KTSP is implemented in national education. These are outlined several reasons as stated by Rohman(https://www.kompasiana.com/fathurrohman/551b8f71a333311ae28b659ed/en glish-ktsp-dengan-segala-problematikanya):

1. In relation to cultural diversity, customs, social, resources and traditions, it is undeniable that Indonesia has it all. KTSP is presented as a preparatory step to optimize all diversity. With the decentralized education system, an educational institution is expected to be able to optimize and preserve the diversity possessed by their respective regions.

2. In each educational institution, the problems faced are not just one. Problems that exist in one educational institution do not necessarily occur in other educational institutions. KTSP, which is made directly by the education unit, is expected to be a problem solving in the education unit itself. Because the most familiar with an educational institution is the institution itself, in this case all the teaching staff and education at the institution.

3. Providing opportunities for all elements of education, namely schools, families and communities to play an active role in advancing an educational institution. The role of the school committee, which consists of representatives of parents and local 
community leaders, is expected to be able to contribute ideas and suggestions that will later be used as learning that aims to develop potential and meet the needs of the region.

According to this basis, the researchers were interested in conducting research related to Islamic Boarding School Leadership Policy in the Development of Islamic School Curriculum inDarularafah Boarding School, Deli Serdang Regency.

\section{Definition of Educational Policy}

The word policy comes from the word policy. The policy itself is etymologically taken from Greek, Sanskrit and Latin. The root word "policy" in Greek is "polis" means the city state, while Sanskrit "pur" means city. This word develops in Latin "politic" which means state. In Middle English the word "policie" refers to actions related to state matters and government administration. As long as the word "policy" is the same as the origin of the two Latin words, namely "polis" and "politic". It seems that this last thing can provide an explanation for why in modern languages, such as Germany and Russia only have one word (politic, political) which both refers to policy and politics (Su'ud: 2011: 2). For this reason, policies direct and require decision making.

Veithzal and Sylviana argue that the policy is the limit of decisions to guide the future (Vithzal, 2010: 97). Another opinion suggests that the policy not only regulates the operating system internally, but also presents definitions relating to functions definitively among the systems (Tilaar, 2009: 7). Then Hasbullah (Hasbullah, 2015: 37) gives an understanding of policy as things that take care of general problems, this means government administration. In conclusion, policies emphasize actions (products), namely policies that are determined subjectively.

It can be concluded that the components of policy understanding include: 1) Goals or desirable goals, 2) Plan which is the specific meaning to achieve goals, 3) Programs, namely efforts that are authorized to achieve goals, 4) Decision, namely actions to determine goals, make plans, carry out and assess plans, 5) Effect, namely the consequences of the plan (intentional or not, primary or secondary, previously calculated or not, previously estimated or not). While Syafaruddin explained that policy means a set of goals, principles and regulations that guide an organization, policy thus covers the overall direction of the organization "(Syafaruddin, 2008: 76). For this reason, policy is the result of top management decisions that are made carefullyof which essential are the goals, principles and rules that direct the organization. 
Masyhud and Khusnurdilo asserted that the policy is a basic form of plan in carrying out a work that is fully made rationally through the optimization of strategies to find the best alternative in order to achieve maximum goals (Masyhud, 2005: 47). Policy is seen as a guideline for action, limiting behavior, and assistance for decision makers "(Pongtuluran, 1997: 7). The existence of policies in an organization is very important, because it is used as a behavioral guide in various strategic activities to achieve organizational goals. Based on this opinion, basically, thepolicy is an action that leads to a specific goal and not just a decision to do something. Policy should be directed at what the government actually does and not just what the government wants to do.

Abidin concluded that public policy contains three connotations, namely: government, society and the public. So, it can be concluded that this meaning includes the subject, object and environment of the policy, therefore public policy is a government policy that with its authority can force people to obey it (Abidin, 2006: 22).

The description above shows that the policy means a set of objectives, principles and regulations that guide an organization, thus the policy covers the overall direction of the organization. The statement can be concluded that policy is the result of top management decision making in the form of goals, principles, and rules relating to strategic matters to direct managers and personnel in determining the future of the organization which has implications for people's lives, it means that strategic decisions are determined beforehand to become a benchmark for implementing the management of the life of the wider community. In its journey, the policies set by the state will come in contact with all lines of the nation's problems, one of which reaches education. Education policy can simply be translated as government policy in the education sector.

Education policy is public policy in the field of education. Encyclopedias state that education policy is concerned with a collection of laws or rules that govern the implementation of the education system, which includes the objectives of education and how to achieve these objectives (Nugroho, 2006: 36). Mark and O'Neil argue that education policy is the key to excellence, even the existence of countries in global competition, so education policies need to be given top priority in the era of globalization. One of the main arguments is that globalization brings the value of democracy. The resultant democracy is democracy that is supported by education.

Marget E. Goertz (Nugroho, 2006: 36) also argues that education policy deals with the efficiency and effectiveness of the education budget. As stated earlier, education policy is understood as part of public policy, namely public policy in the field of education. Thus the education policy must be in harmony with public policy. In the context of public policy 
in general, namely development policy, policy is part of public policy. Educational policy is understood as a policy in the field of education, to achieve the goals of state development in the field of education, as one part of the overall development goals of the country.

\section{Function of Educational Policy}

Educational policy provides a very significant role for education scientists. In general, there are at least two interests that are very closely related between education policy and these scientists. The first, with the education policy scientists is expected to provide corrections to improve education in the context of its implementation. The second, as a forum in formulating quality education for the future (Hasbullah, 2015: 41).

Public policy in education ensures that education becomes a public interest. In the beginning, schooling, education was a private affair provided by a small part of the community. However, the school was created by the government for all citizens. Furthermore, the policy in education is determined by the government, which is regulated not only in the curriculum, pedagogy and assessment, but also by the condition of the teacher and maintenance of the school's physical facilities. The policy functions in education are: 1) providing accountability for cultural norms that the government needs to have in education and, 2) institutionalizing accountability mechanisms to measure student and teacher performance (Fattah, 2013: 132-134).

The factor that determines change, development, or organizational restructuring is the implementation of organizational policy so that it can be felt that the policy really works well. The nature of policy is in the form of decisions of which substance is goals, principles and rules. The format of the policy is usually recorded and written as a guideline by the leadership, staff, and organizational personnel, as well as their interactions with the external environment.

Policies are obtained through a policy-making process. Policy making is seen as a number of processes from all parts and relates to the social system in making system goals. The decision-making process takes into account external environmental factors, input, process (transformation), output, and feedback from the environment to policy makers. Regarding this issue, policy is seen as: 1) Guidelines for action, this reveals that education policy has a central position in determining a reference in the implementation of educational programs as well as demands on where the direction of the education system will be and runs, 2) Limiting behavior. If it is associated with education, education policy cannot be separated from the norms and rules in each actualized action related to 
educational activities, and 3) assistance to decision makers. Education policy here is the spearhead in making the right and correct decisions after going through a series of formulation processes by educational policy makers (Pongtuluran: 1995: 7). Policy is made to be a guideline in acting, directing activities within the organization to achieve the stated goals. In other words, policy is a general line to act for decision making at all levels of the organization.

Sayafaruddin further argued that the function of education policy was seen as: (1) guidelines for implementing education, (2) limiting education behavior, and (3) assistance for decision makers in the context of education (Syafaruddin, 2008: 78). The existence of education policy is very important, because it is used as a behavioral guide in various strategic activities to achieve educational goals.

\section{Formulation of Educational Policy}

Education policy is an intensive and comprehensive nature. The policy made is intended to overcome a problem that is complicated. Good policy is a policy made based on the aspirations and siding with the community and the reality that exists, responding to various interests and minimizing the loss of certain parties. Likewise with the education policy, it should be considered many things, because it involves the public interest which has a very large impact (Hasbullah, 2015: 63). The education policy that is made must be wise, in the sense that it does not cause new educational problems that are bigger and more complicated when compared to the problems that are to be solved. Education policies that are made must encourage productivity, quality, and shared life in the education sector effectively and efficiently.

Syaiful Sagala (2008: 99) suggests that in general there are approaches used in policy making as follows:

1) Empirical Approach

The empirical approach is emphasized mainly on the explanation of various causes and consequences of a particular policy in the field of education that are factual and the types of information produced are descriptive and predictive. Empirical policy analysis is expected to produce and transfer important information about values, facts and educational actions.

2) Evaluative Approach

Evaluation according to Imron is "one of the activities that intends to know how far an activity can be carried out or not, succeed as expected or not". The emphasis of this evaluative approach is mainly on determining the weight or benefits (values) of any 
policies that produce evaluative information. Evaluation of policies helps answer evaluative questions, namely how the value of a policy is and according to the value in which the policy is determined.

Formulation is the stage of implementation of a policy. Interaction is an important concept in policy steps that refers to a relationship that is sometimes very complex. There are two things that must be considered in implementing a policy, namely: (1) the formulation of policy objectives must be clearly included in the target group; who plays a role; and how the policy must be implemented, and (2) proportional supporting funds, without policy funds it will never be realized. The policy step refers to the activity of carrying out policies in the real world, both those carried out by the organs of the government and the parties specified in the policy. The policy step itself is usually referred to the implementor, and the target group. Policy measures are those that are officially recognized as individuals or institutions which are responsible for implementing programs in the field. The target group is to appoint the parties as the object of policy (Hasbullah, 2015: 38).

The opinion above explains that there are at least three important elements in the process of implementing the policy, namely: (1) the existence of a program or policy implemented, (2) the target group, namely the target groups and expected benefits of the program, changes or improvements (3) implementing elements (implementors), both organizations or individuals to be responsible for obtaining the implementation and supervision of the implementation process.

Whether a policy is implemented or not, including education policy is determined by many factors. Policy experts have a diverse view of the factors that influence the success or failure of policy implementation. Furthermore, the factor that must be considered in the policy step is the aspect of the content of policy which will have an influence on the social, economic and political environment, as well as the context or implementation environment. Both aspects are understood as factors that can influence the success or failure of the policy step process. Policy formulation is the first very important step in policy making. This stage is the main key that must be done before a policy issue is considered in the government's policy agenda and finally becomes a policy. Without first entering the agenda, it is not possible for a problem that exists in the community how important the problem can be raised as a policy by the government (Hasbullah, 2015: 68).

In formulating a policy, the first it must make a policy agenda, whether it is a systematic agenda namely all issues which are generally seen by political society as things 
that deserve public attention, as well as the government's agenda, namely a series of problems that are actively and seriously from policy makers.

Good policy is a policy made based on the aspirations and siding with the community and the reality that exists, responding to various interests and minimizing the loss of certain parties (Hasbullah, 2015: 63). Likewise, in formulating policies in education, the policies set must be carefully considered regarding the public interest.

The policy-making process is a political process that takes place in the stages of political policy making, where political activity is explained as a policy-making process, and visualized as a series of stages that are interdependent, arranged in the order of time. There are at least three processes adopted in the policy, namely; formulation, implementation, and evaluation (Jputt, 1980: 30). The three policy processes are described so that holistically the meaning of the policy as a management process can be well understood. While the stages in the policy making process as stated by Dunn, agenda setting, policy formulation, policy adoption, policy implementation, and policy evaluation".

It can be explained that 1) Arrangement of the agenda, this activity has the characteristic that officials who are elected and appointed to place problems on the public agenda. Many problems are not touched at all, while others are delayed for a long time. 2) Policy formulation, this activity where officials formulate alternative policies to overcome problems. Alternative policies see the need to make executive orders, judicial decisions and legislative actions. 3) Adoption of policies, where alternative policies are adopted with the support of legislative majority, the consensus among director of institutions, or judicial decisions. 4) Implementation of policies, this activity is characterized by policies that have been taken and implemented by administrative units that mobilize financial and human resources.

The explanation above is in line with the conclusion of Fatkuroji (2012: 21) that the stages in the policy making process are as follows:

\section{a. Agenda Setting}

Preparing a policy agenda is the first very important step in policy making. This stage is a key step that must be passed before policy issues are raised on the government's policy agenda and eventually become a policy. Agenda arrangement is a strategic phase and process in the reality of public policy. This process has space to interpret what is called a public problem. Top leaders prepare draft laws and send to staff to be discussed. 


\section{b. Policy formulation}

The stages of policy formulation are the real mechanism for solving public problems that have become the government's agenda. This stage is more technical in nature, compared to the more political agenda setting stages, by applying various analytical techniques to make good decisions. Economic models and decision-making theories are analyzed which are useful for making the best decisions and minimizing the risk of failure. Some activities that need to be considered in making good policies, namely: (1) the formulation of educational policies do not dictate specific decisions or only create a specific environment, (2) policy formulation can be used to deal with problems or situations that arise repeatedly.

Problems that have been included in the policy agenda are then discussed by policy makers. The officials formulated alternative policies to overcome the problem.

c. Adoption / Legitimacy Policy

Legitimacy comes from the word "legitimacy" which means giving power or authority (authorization) on the basis of the operation of the political system, including the process of drafting a plan, a proposal to solve the problems that grow in the community.

Policy legitimacy means an alternative policy adopted with support from the majority of the legislature, consensus among the directors of educational institutions. The policy process requires legitimacy in order to obtain recognition from the public. Recognition from the community is very important, so that when the education policy will be implemented there will be no rejection from the community. The more people who actively participate in the implementation, the policy is considered increasingly successful.

\section{Definition of Curriculum}

Curriculum development is a comprehensive term, which includes: planning, implementation and evaluation. Curriculum planning is the first step in building a curriculum when curriculum workers make decisions and take action to produce plans that will be used by the teachers and students. Application of the curriculum or commonly called curriculum implementation seeks to transfer curriculum planning into operational actions. Curriculum evaluation is the final stage of curriculum development to determine the extent of learning outcomes, the level of achievement of planned programs, and the results of the curriculum itself. 
At first the term curriculum was found in the world of statistics in ancient Greek times, which originated from the word Curire which means runner, and Curete means a place to race or a race place. While the Curiculum means "plural" which must be taken by runners. When viewed in Webster's 1812 dictionary, the curriculum is (1) a race course, a place for running; a chariot, (2) acourse, in general; applied particulary to the course of study in a university Nurdin: 2003: 33). The meaning of the curriculum as the definition has two meanings, namely a distance for the race that must be taken by runners, and also interpreted as a chariot, which is a kind of horse-drawn carriage in the past that was used to carry a person from the start or finish.

Likewise expressed by Erwin and Salim that literally the curriculum comes from the Latin "curriculum" which means "a little race course" which is the distance that must be taken in sports competitions (Mahrus, 2009: 81). Further developments in the term curriculum are used in the world of education and teaching, as contained in Webster Dictionary in 1955, the curriculum is defined as follows: "a course, especially a specified fixed course of study, as in a school or college, as one leading to a degree". This definition means that the curriculum is a number of subjects in the school or at the academy / college that must be taken by students to achieve a degree (level) or diploma (Mahrus, 2009: 34).

Thus, it can be concluded that the curriculum is a set of plans and arrangements regarding the purpose, content, and learning material and the methods used as guidelines for the implementation of learning activities to achieve certain educational goals.

\section{Curriculum Development and Quality Improvement Policy}

Not only involves people who are directly related to the world of education, but it involves many people, such as: politicians, entrepreneurs, parents of students, and other elements of society who feel an interest in education. Implementation of curriculum development is a change in the curriculum, such as the reality in the field of curriculum is always replaced in accordance with the demands of the times and the development of science and technology. And curriculum development policies must be poured into learning. According to the large Indonesian dictionary, learning is "a process, or a way of making people or living things learn" (Ministry of Education and Culture, 1995: 14).

Whereas OemarHamalik limits it that learning is a combination which consists of human, material, facilities, equipment and procedures that influence each other to achieve goals. Humans are involved in teaching systems consisting of students, teachers and other personnel, such as laboratory personnel. Material, including books, blackboard, photography, audio and video tape. Facilities and equipment, consisting of audio visual 
equipment, classrooms, as well as computers. Procedures include schedules and delivery of information, practice, learning and so on (Hamalik, 1995: 57).

The term learning is a development of teaching terms and the terms of teaching and learning that we can debate, or we just ignore the important meaning of all three, learning is an effort made by a teacher or educator to teach students who are learning. In formal education, learning is a task charged by the teacher, because the teacher is a professional staff prepared for it. Learning inmadrasah (Islamic school) is increasingly developing from traditional teaching to modern learning systems. Learning activities are no longer merely teaching activities that ignore learning activities, namely teaching activities and implementing teaching procedures in face-to-face learning. However, learning activities are more complex and carried out with varied learning patterns.

There are four broad outlines of learning patterns, the first, learning patterns between teacher and students without using assistive devices / learning materials in the form of teaching media. This learning pattern is very dependent on the ability of the teacher to remember learning material and convey the material verbally to students. The second, the pattern (teacher plus teaching media) with students. In this learning pattern the teacher has been assisted by various learning materials called learning sense tools in explaining and modeling an abstract message. The third, the pattern (teacher) plus (media) with students. This learning pattern has taken into account teacher limitations, which cannot be the only source of learning. Teachers can take advantage of various learning media as learning resources that can replace teachers in learning. So this pattern of learning patterns alternates between the teacher and the media in interacting with students. The consequence of this learning pattern is that learning materials must be prepared which can be used in learning. The Fourth, media patterns with students or distance learning patterns use media or learning materials prepared.

Based on the description above, then learning is not just teaching, because the successful learning must provide a lot of treatment to students. The teacher's role in learning is more than just a teacher (informant), but the teacher must have multi roles in learning. In order for the learning patterns to be applied also vary, the learning material must be prepared in a variety of ways as well. According to Adams \& Dickey, the role of the teacher is actually very broad, including: (a) the teacher as instructor), (b) the teacher as a guide or counselor, (c) teacher as a scientist, and (d) the teacher as a person. Even in the broadest sense, where schools change function to become a liaison between technology and society, and schools are more actively involved in the development, so the role of teachers is broader. 
While Mardianto gives a description of the definition of learning, it is a systematic and systemic activity and process that consists of several components, namely: teacher, curriculum, students, facilities and administration. Each component is not partial (separate) or runs on its own, but must run on a regular basis, interdependent, complementary and sustainable. For this reason a plan and management of good learning is needed, which are developed in order to achieve learning goals (Mardianto, 2010: 9). Dimyanti and Mudjiono illustrate how the role of teachers in engineering learning and student learning actions act, so that the development of students according to the principle of emancipation leads to wholeness and independence (Dimyati, 1999:4).

For this reason, learning will be carried out well and produce quality graduates not only depends on how great the material is, but there must be teachers who are active, creative, and continue to innovate in developing the curriculum.

\section{Research Method}

This study used a qualitative method. Qualitative method is a research procedure that produces descriptive data in the form of expressions or notes from the person themselves or observable behavior. This approach leads to circumstances and individuals holistically (intact). Thus, the selection of this method is based on the consideration that this study aimed to describe the characteristics of the research subject in terms of making the policies of the boarding school leaders in curriculum development at the Darularafah Boarding School boarding school in Deli Serdang Regency.

The qualitative research approach as a scientific method is often used and implemented by a group of researchers in the field of social sciences, including education and management education. A number of reasons were also raised which essentially point out that qualitative research enriches the results of quantitative research. Qualitative research is carried out to build knowledge through understanding and discovery. This qualitative research approach is often called naturalistic research methods, because the research is carried out in natural conditions (Sugiono, 2014: 1).

The process of this research was carried out repeatedly in the field. Every time the researchers came, did observations and recorded data about the process of implementing the curriculum in Islamic school learning at the Darularafah boarding school where this research was conducted. Furthermore, the data were arranged in a descriptive and reflective manner and analyzed. The process was carried out continuously during conducting research (Bogdan: 1993: 30). 
This research was focused on implementing policies. This empirical study intended to examine the policies of the leadership of the Darularafah Boarding School boarding school in Deli Serdang Regency, North Sumatera province, in curriculum development. The policy of the leadership of the Darularafah Boarding School boarding school in Deli Serdang Regency includes policy formulation, policy implementation, policy performance, and stakeholder support related to the policies of the boarding school leaders in developing the Islamic school curriculum at the Darularafah Boarding School boarding school in Deli Serdang Regency, therefore the use of qualitative method was appropriate in expressing the facts as empirical truths in this study.

\section{Findings And Discussion}

The first Findings, the policies of the boarding school leaders in developingthe Islamic school curriculum in Islamic boarding schools are carried out through annual meetings and deliberations attended by leaders, chiefs of fields, fields of education and teaching, human resources, extracurricular fields, caring field, school principals, and the teachers in relation to elaborating the decisions produced through the annual work meeting and deliberations of the leaders and stakeholders of the Darularafah Boarding School. The meeting discussed five formulations of work programs related to the system of movement, organization and leadership, networks, resources and service actions. According to Jones, policy is a fixed decision that is characterized by consistency and repetition of the behavior of those who make and from those who comply with these regulations (Hasbullah, 2014: 38).

Basically, the policy making process is a complex process because it involves many processes and variables that must be studied. It means that in the formulation or policy making we understand that there are actors or participants involved in the process of making the policy. This is something that must be considered in the policy-making process at the Darularafah Boarding School.

Therefore, the Darularafah Boarding School as one of the Islamic-based educational institutions, was founded on the basis of the desire, encouragement and enthusiasm to broadcast Islamic values. Therefore the Darularafah Boarding Schoolalways strives to develop the quality of Islamic education by presenting teaching programs with modern teaching methods, so that there is always innovation and not to miss the changes and development of the times so the policies are carried out in the effort to develop boarding school. 
In the formulation of a policy, it actually begins with the stages of planning, organizing and controlling then performs policy formulation by involving the structural components that exist in the institution. The activities in the process of making a policy are displayed in a series of interdependent stages arranged in a sequence of time; agenda setting, policy formulation, policy adoption, policy implementation and policy assessment.

From each of these formulations, it will be described in the form of activities or programs that implement these programs through meetings which are attended by boarding school leaders, chairmen of fields including education and teaching, human resources, extracurricular fields, parenting fields, Madrasah Aliyah (Islamic Senior High School) principals, Madrasah Tsanawiyah (Islamic Junior High School) principals and boarding school stakeholders in relation to elaborating decisions made through annual meetings and deliberations. In the meeting discussed five work programs in relation to the system of movement, organization and leadership, networks, resources and service actions. Each of these programs will be elaborated in the form of activities that implement the policies of the boarding school leaders in the development of the Islamic school curriculum in the boarding school.

The second findings, one of the boarding school programs in developing the Islamic school curriculum through improving teacher quality by providing education and training. Only with adequate education and training is done to the teachers so they will become valuable human resources and very important in increasing productivity. Thus, programs to improve productivity or performance of education personnel depend on the quality of the workplace, management, and the desire to contribute to increasing the productivity of teachers. That means, there must be a policy of improving human resource education through quality and sustainable education and training ".

The implementation of the teacher training program is indeed based on the needs of the teaching profession at this time. Other research results show that there are several reasons for the importance of increasing teacher competency through training programs. The first: teacher needs for new knowledge and skills. The best teacher is prepared, not only in teacher or college education, but also when they start and are working in a school. The teacher must always be given input of knowledge and skills while becoming an educator. It also means that competence and even professionalism are achieved, not just discussed. That teaching will succeed only if the teacher has met professional standards, which are set forth in the national educational standards about educators. 
Madaniapromotes among the reasons why this school is worthy of being chosen by parents is the competent teachers.

The second: teachers must understand the learning process, students and also understand the importance of sharing knowledge and experience with others, to find better ways to teach. Knowledge of better ways of learning is often obtained by teachers from various experiences with fellow educators, juniors to seniors.

The third: teachers are prepared to be able to deal with changes at present, and in the future. Through the training, teachers are expected to be able to develop intellectual, emotional and spiritual aspects of students, so that they are ready to face the future (Mustafa, 2015: 129-130). It can be concluded from the discussion above that the steps of the implement of the policy inDarularafah boarding school are implemented as the chief of education and teaching program (DIKJAR) by arranging annual agendas and conducting leadership meetings and stakeholders and always monitoring the class with escort and giving rewards and support for teachers who implement the program and who do not.

The third finding, the performance of the policy implementation of the Darularafah Boarding School leadership has become an important point that needs to be considered in the development of the curriculum in the Darularafahboarding school. Whether or not a policy is implemented, including education policy, is determined by many factors. Policy experts have a diverse view of the factors that influence the success or failure of the policy implementation. Furthermore, the factor that must be considered in the policy step is the aspect of the content of the policy that will have an influence on the social, economic and political environment, as well as the context or implementation environment. Both aspects are understood as factors that can influence the success or failure of the policy step process.

Basically, curriculum development is the level of accuracy (validity) and the reliability of the principle which is used. This has something to do with the sources of the principle of curriculum development itself. There are data, facts, concepts, and principles whose level of trust are undoubted because it has been empirically proven through repeated research. There are also data that have been empirically proven, but are still limited in certain cases so that they cannot be generalized. There are even data that have not been proven in a study, but it has been proven in life and according to common sense considerations are considered logical, good, and useful (MKDP Team, 2012: 65).

In line with the discussion above, the policy performance of the Darularafah boarding school was implemented in the development of the Islamic school curriculum 
in the Darularafah boarding school that with the performance of the curriculum needed team work in formulating and implementing it in programs that showed improvement in education and learning design seen from increasingly teachers' creativities design learning and learning methods that are increasingly diverse so that the quality and quantity of santri / diyah(student) increases.

The fourth Findings, the stakeholders' support in implementing the policies of the boarding school leaders in the internal environment of the Darularafah Boarding School supports Islamic boarding school programs by involving teachers in all boarding school activities in the form of training, formulating policies and then socializing and implementing them from leaders, field leaders, principals and teacher.

Curriculum development does not only involve people who are directly related to the world of education, but also involves many people, such as politicians, entrepreneurs, parents of students, and other elements of society who feel an interest in education. Implementation of curriculum development is a change in the curriculum, such as the reality in the field of curriculum is always replaced in accordance with the demands of the times and the development of science and technology. And curriculum development policies must be poured into learning. According to the large Indonesian dictionary, learning is "a process, or a way of making people or living things learn" (Ministry of Education and Culture, 1994: 114).

Community involvement in curriculum management is intended to be able to understand, help, and control the implementation of the curriculum, so that educational institutions or schools are required to be cooperative in identifying curriculum needs, designing curriculum, determining curriculum priorities, implementing learning, assessing curriculum, controlling and reporting sources and curriculum results, both to the community and to the government. In addition, each education unit must have guidelines governing the education unit curriculum and syllabus level. This was stated in PP RI No. 19 of 2005 Article 52 verse (1) concerning National Education Standards.

In line with Dian Sukmara's statement, that the government and the community must sit together to set educational standards that must be achieved to be used as a foundation and barometer of the decline of education in the country. On the other hand, he stated that decentralization of the curriculum is an effort to develop curriculum programs suited to the potential, characteristics and needs of the region, taking into account: (1) Characteristics of social, economic and power systems, (2) Level of evolution and administrative complexity, (3) Diversity regional government, (4) Availability of 
specialized technical personnel, and (5) Involvement of government and private assistance (Sukmara, 2005: 12-13).

Based on the description above that the five concerns in the implementation of education which implement the pattern of curriculum development in a decentralized manner are demanded by the cooperation and participation of various parties, not only the education and implementation of the curriculum. This is based on the assumption that all parties are morally responsible for the smooth running and successful implementation of education.

The researchers concluded that the discussion above showed that the stakeholders follow the policies of the boarding school leaders so that they were able to work together well internally and structurally. This meant that the internal stakeholder environment strongly supported all the implementation of the boarding school leadership's policies in the effort to develop the Islamic school curriculum at the Darularafah Boarding School in Deli Serdang regency by participating in the annual meeting program activities, participating in socializing the program, implementing the program in each existing field and implementing it that in line with the policies and vision, mission and objectives of the Darularafah Boarding School.

\section{Conclusion And Recommendation}

\section{Conclusion}

1. The policy formulation of the boarding school leaders in the development of the Islamic school curriculum at the Darularafah Boarding School was carried out through annual meetings and deliberations attended by leaders, chiefs of fields, fields of education and teaching, human resources, extracurricular fields and the field of caring, principals, teachers, committees, and communities in relation to elaborating decisions made through annual work meetings and deliberations of leaders and stakeholders of the Darularafah boarding school. Formulating an increase in the development and supervision of curriculum in classroom and extracurricular learning and night tutoring in a holistic, integrative, well-managed manner, and competitive and superior. The meeting discussed five work programs in relation to the system of movement, organization and leadership, networking, resources and service actions. Each of these programs would be described in the form of activities that implement these programs.

2. The implementation of the fifth formulation of curriculum development programs implemented in the Darularafah boarding school was carried out at the leadership 
and stakeholder meetings called the annual meeting held at the end of each year, then socialized to and through the prepared fields of education and teaching, human resources field, care and extracurricular fields. Each program contains activities that would be carried out during each year, related to improving the quality of teachers, the resource development program became a reference in its implementation.

3. The performance of the implementation of the boarding school leadership's policies in the development of the Islamic school education curriculum at the Darularafah boarding school where the curriculum was arranged according to its development and in accordance with the needs of the boarding school in issuing well-used graduates. The performance of the policy implementation of boarding school leaders showed an increase in the knowledge and skills of religious teachers in developing the curriculum.

4. The stakeholders' support in implementing the policies of the boarding school leadership in the development of the Islamic school curriculum at the DaruarafahBoarding School where the internal stakeholders strongly support the implementation of the boarding school leadership's policies in developing the Islamic school curriculum at the Darularafah Boarding School in Deli Serdangis by participating in the annual meeting program as well as socializing the program, implementing the program in every field that exists and implementing it in line with the policies and vision, mission and objectives of the DarularafahBoarding School, as well as support from the community who continue to support morally and materially in the form of donations.

\section{Recommendation}

1. In the process of formulating educational policies carried out by boarding schools in the development of Islamic school education curricula, it is expected to involve all stakeholders, starting from foundations, principals, religious teachers, santri / dyah, communities so as to absorb aspirations and needs, and policies that are made will be more effective because they are shared aspirations or expectations.

2. The curriculum development program is further enhanced by inviting competent speakers, so it is expected that more skills will be faced in facing the world of work so that it can have a major impact on santri / dyah.

3. It is expected that the participation of the foundation in terms of monitoring and supervision as well as the follow-up of the policy program implemented. 


\section{References}

Abidin, Said Zainal. KebijakanPublik. Jakarta: SuaraBebas, 2006.

Dimyanti dan Mudjiono. Belajar dan Pembelajaran. Jakarta: Penerbit Rineka Cipta, 1999.

Depdikbud. KamusBesarBahasa Indonesia. Jakarta: BalaiPustaka, 1995.

Fattah, Nanang. Analisis Kebijakan Pendidikan. Bandung: Remaja Rosdakarya, 2013.

Rohman.https://www.kompasiana.com/fathurrohman/551b8f71a33311ae28b659ed/me ngenal-ktsp-dengan-segala-problematikanya. visited 30 Mei 2019, pkl.oo.30.

Hamalik, Oemar. Kurikulum dan Pembelajaran. Jakarta: Bumi Aksara, 1995.

Hasbullah, H.M. KebijakanPendidikan: DalamPersfektifTeori, Aplikasi, dan KondisiObjektifPendidikan di Indonesia. Jakarta: Raja GarfindoPersada, 2015. . Kebijakan Pendidikan. Jakarta : PT. Raja Grafindo Persada, 2014.

Fatkuroji. Analisis Implementasi Kebijakan Pembelajaran Terpadu Terhadap Minat Konsumen Pendidikan: Studi SDIT Bina Amal dan SD Al-Azar 29BSB

Semarang. Semarang: UIN Walisongo, 2012.

Jputt, Allen and J Fred Springer.Policy Research. New Jersey: Prentice Hall, 1990. Masyhud Sulthon dan Moh. Khusnurdilo. Manajemen Pondok Boarding school. Jakarta: Diva Pustaka,2005.

Pongtuluran, Aris. Kebijakan Organisasi dan Pengambilan Keputusan Manajerial. Jakarta: LPMP, 1995.

Mardianto. Media PembelajaranPendidikan Agama Islam. Medan: Institut Agama Islam Negeri, FakultasTarbiyah, 2010.

Musfah, Jejen. Peningkatan Kompetensi Guru. Jakarta: Kencana, 2015.

Nugroho, Riant. Public Policy: Teori Kebijakan, Analisis Kebijakan, Proses. Jakarta:Elex Media Komputindo, 2008.

Nurdin, SyarifuddindanBasyiruddin Usman, Guru Profesional\&Implementasi Kurikulum. Jakarta : PT. Intermasa, 2003.

Mahrus, Erwin, dan Moh Haitami Salim. Filsafat Pendidikan Islam. Pontianak: STAIN, 2009.

PeraturanpemerintahRepublik Indonesia Nomor 19 Tahun 2005 tentangStandar Nasionalpendidikan,TambahanLembaran Negara RI Nomor 4496, tt.

Robert, Bogdan dan Steven J. Taylor, Kualitatif Dasar-dasar Penelitian, Alih Bahasa A. Khozin Afandi. Surabaya: Usaha Nasional, 1993.

Sagala, Syaiful. Administrasi Pendidikan Kontemporer. Bandung: Alfabeta, 2008. 
Sa'ud, UdinSyaefudin. PengembanganKebijakandalamKerangkaOtonomiDaerah. Bandung: Alfabeta, 2011.

Sugiyono. Memahami Penelitian Kualitatif. Bandung: Alfabeta, 2014.

Sukmara, Dian. Implementasi Program Life Skill, Dalam Kurikulum Berbasis Kompetensi pada Jalur Sekolah. Bandung : Mughni Sejahtera, 2005.

Syafaruddin. EfektivitasKebijakanPendidikan. Jakarta: RinekaCipta, 2008.

Veithzal, Rivai dan MurniSylviana.Education Management. Bandung: Citapustaka Media Perintis, 2010.

Tilaar, H.A.R. Kekuasaan Dan Pendidikan.Jakarta: Rineka Cipta, 2009.

Tim Pengembang MKDP. Kurikulum dan Pembelajaran. Jakarta: Rajawali Pers, PT. Raja Grafindo Persada, 2012. 